\title{
NEEDS AND SUITABILITY ASSESSMENT FOR HAY LAND PLANNING
}

\author{
I.Myagmarjav $^{1 *}$ and P.Myagmartseren ${ }^{2}$ \\ ${ }^{1}$ School of Agroecology, Mongolian University of Life Sciences, Ulaanbaatar, Mongolia \\ ${ }^{2}$ School of Arts and Sciences, National University of Mongolia, Ulaanbaatar, Mongolia \\ *Corresponding author: myagmarjav@muls.edu.mn
}

\begin{abstract}
The paper addresses planning issues of hay land based on new methods of suitability and need's assessment of local area. In order to develop the hay land future use and planning for 2023 of Erdenetsagaan soum, Sukhbaatar aimag, the assessment of the haymaking situation, the number of livestock growth and needs of nutritional resources for animal husbandry were calculated. According to the tested new suitability assessment of hay land, 4.37 percent or 74164 ha of land are most suitable, and 29.21 percent or 496014.3 ha are unsuitable. In order to calculate the nutritional needs of livestock in the future, the demand of green fodder for hay cut is estimated at 6712 tin 2023. The need for this fodder supply requires 8391 ha hay fields in 2023. Thus, demand (6712 thay from 8391 ha of field) of green fodder will be supplied after proper implementation of plan (74164 ha suitable field to hay land usage).
\end{abstract}

KEYWORDS: Suitability evaluation, need's calculation, green fodder planning analysis

\section{IINTRODUCTION}

Mongolian livestock are consuming more than 95 percent of fodders from natural pasture, and rest of 2$5 \%$ belong to the supplementary hay fodder and overgrazing increases chronic malnutrition, illnesses, and mortality [1]. For the purpose of increase and preparation of supplementary nutrient during cold season, it is important to identify the areas that can be used for haymaking and to plan future use and protection management of hay land. In winter, hay fodder prepared from natural pastures is an important source of feed for livestock during the dzud and other natural disaster. The assessment of the suitability is

\section{METHODS AND MATERIALS}

The following research methods were used for the newly developed hay land planning approach, which is based on the assessment of the suitability and the number of livestock up to 2023's and their estimated fodder rate.

- Suitability assessment is based on multicriteria analysis techniques of geographical information system (Baban and Wan-Yusof, 2003) [3]. Assessment concludes two phases of data preparation and multi-factor analysis. The first phase will establish the baseline constraints for the basic planning requirements. The second step is to the process of determining the ideal use of the most favorable future conditions for land use with specific criteria [2]. However, there is no methodology for assessing suitability of hay land in our country. Therefore, we have developed a new hay land suitability assessment methodology. Due to importance of to calculate the potential location of haymaking and nutritional needs of livestock when planning the hay land, we are introducing newly developed needs assessment and planning methodology in pilot area of Erdenetsagaan soum.

analyze multivariate of factors by weighting the AHP (Analytical Hierarchy Processing) software [4].

- Calculation of the number of livestock and livestock growth analysis had been processed by the guidelines of Ministry of Food and Agriculture about the calculation of appropriate composition and rate of the livestock number [5].

- Introducing hay land use planning based on the suitability and future needs assessment of hay fodder is main approach of our newly developed planning methodology. Multi- 
criteria analysis method is used when many factors are used in the suitability assessment. Compared to many factors, one is more important than the other, and the weight is higher.

- Analytical hierarchy process was used to rank indicators (Saaty 1977) [6]. This method identifies the weight value by the matrix of the criteria for the indicator. The criteria selected by ranking were used to determine the value of the relative weight to influence the use for the hay field.

\section{RESULT}

Based on the new assessment of the suitability of hayfields and the calculated number of livestock up

\section{Hay land suitability assessment}

According to the literature study (State Land Use Planning, Survey, Project Design Institute, 1988 [7], Purevtseren et al. 1990 [8]) for the site selection of hayfields several factors counted most important. Using the literature study review above mentioned we had been selected five factors for the suitability assessment such as: grass yield, soil moisture, stoniness, plant protein and plant nutrition unit. to 2023, the hay land planning was carried out based on the estimated need of livestock fodder supply.

According to the ranking based on the literature study, the most important of these factors are vegetation yield, soil moisture, and the lowest valued factors are stoniness, plant protein and nutrition unit. Finally, the factors that are to be ranked according to the importance of selecting a suitable place for the hay land are calculated in table 1.

\section{Ranking and weighting of factors for hay land suitability}

\begin{tabular}{clccc}
\hline № & & Factors & Ranking & Relative weight \\
\hline 1 & Yield & 1 & 0.4163 \\
2 & Soil moisture index & 2 & 0.2618 \\
3 & Stoniness & 3 & 0.1610 \\
4 & Protein & 4 & 0.0985 \\
5 & Nutrition unit & 5 & 0.0624 \\
& & & & \\
\hline
\end{tabular}

Table 1.

Assuming the value of the weighted matrices is calculated by the consistency ratio (CR) of 0.0203 is assumed that the ratio between the factors is wellconsisted.

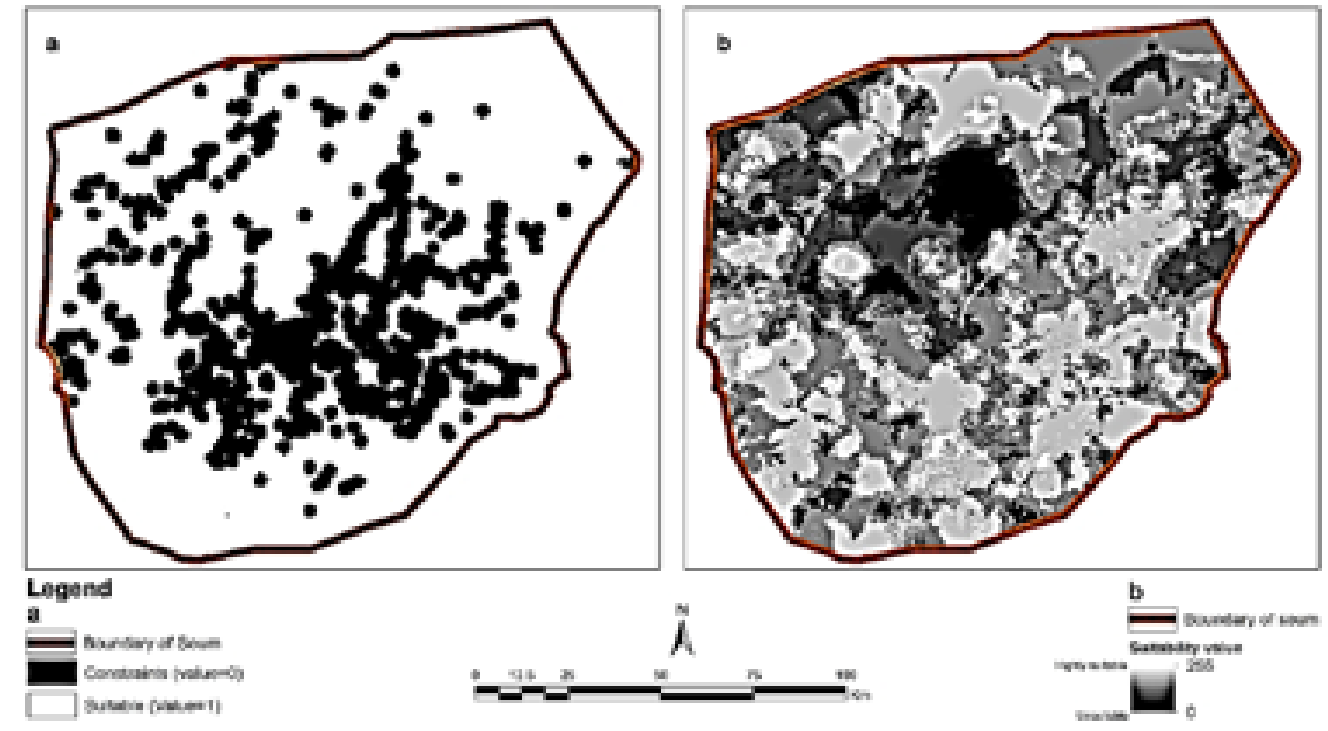

Figure 1. Hay land suitability constraint and factor map 
The figure 1 of the above factors (table 1) was taken with the help of radiometric correction all the pictures were taken from 0 to 255 values, and the higher the values are the more suitable for hay land use. As they all contained the whole range of values between 0 and 255, the maps produced could serve as continuous representations of hay land suitability score. The summary of the constraint situation and factor assessment of the suitability of hay land has been combined and presented in figure 2 .

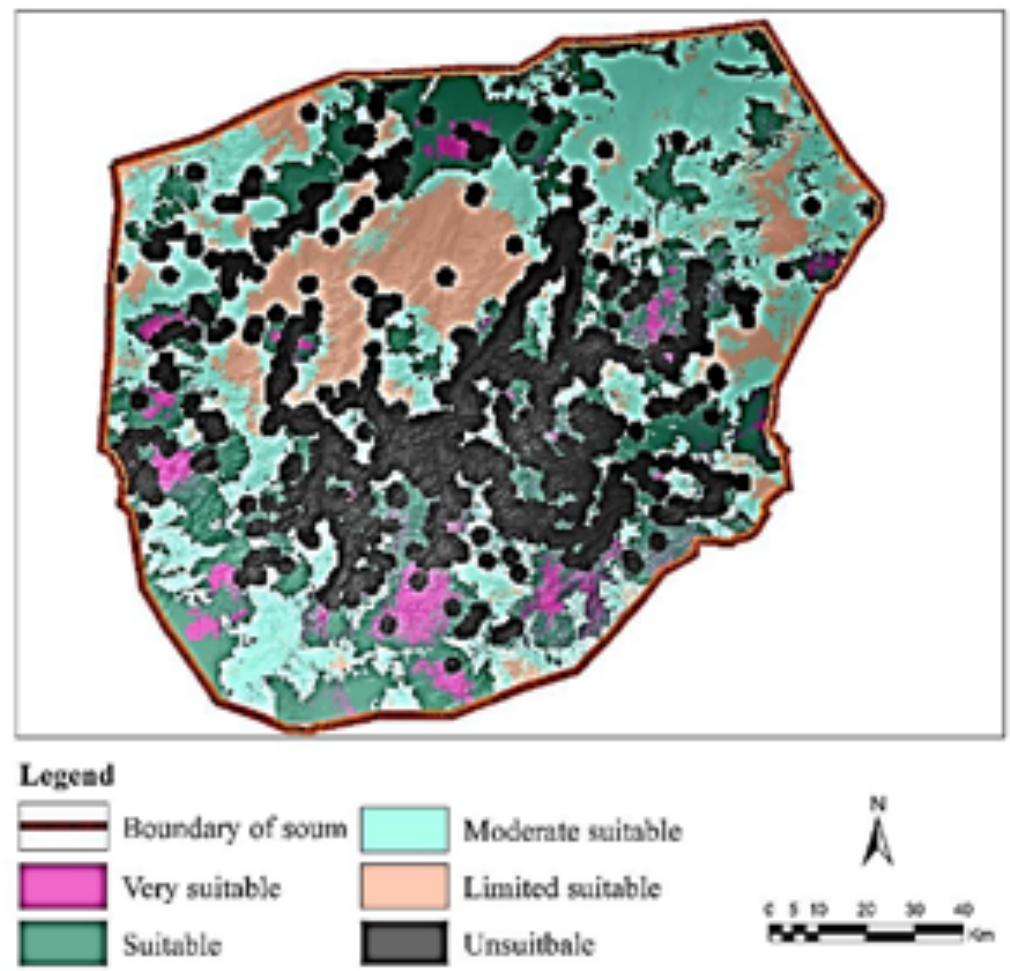

Figure 2. Final suitability assessment map of all factors evaluated with constraint consideration

The suitability of the hay land had been estimated in following classes: most suitable, suitable, moderately suitable, limited and unsuitable (table 2).

Table 2.

Final assessment result of the hay land suitability

\begin{tabular}{|c|c|c|c|}
\hline № & Suitability classes & Area, ha & Percentage \\
\hline 1 & Most suitable & 74164.81 & 4.37 \\
\hline 2 & Suitable & 394430.93 & 23.23 \\
\hline 3 & Moderately suitable & 528371.47 & 31.11 \\
\hline 4 & Limited & 205218.49 & 12.08 \\
\hline 5 & Unsuitable & 496014.30 & 29.21 \\
\hline & Total & 1698200 & 100 \\
\hline
\end{tabular}

According to the tested new suitability assessment of hay land, 4.37 percent or 74164 ha of land are most suitable, and 29.21 percent or 496014.3 ha are unsuitable.

Quantitative Analysis of Fodder Needs

In order to estimate the need for fodder during the planning period, the appropriate livestock structure and circulation had been calculated based on recommendation on proper composition of livestock and recommendation of herd circulation (Ministry of Food, Agriculture and Light Industry, 2013) [9], and sheep unit conversion and hay fodder amount had been calculated according to the methodology of soum development plans (Land Administrationt, Geodesy and Cartography Agency, 2017) [10].

Livestock composition and number estimated (table 3 ) below are the hay fodder need for 120 days of the winter time $[5,11]$. 
The hay fodder need $(100 \mathrm{~kg})$

\begin{tabular}{|c|c|c|c|c|c|c|c|c|c|}
\hline \multirow{2}{*}{$\begin{array}{c}\text { Livest } \\
\text { ock }\end{array}$} & \multirow[t]{2}{*}{2018} & \multirow[t]{2}{*}{2023} & \multicolumn{2}{|c|}{ Sheep unit } & \multicolumn{2}{|c|}{$\begin{array}{l}\text { Total fodder } \\
/ 100 \mathrm{~kg} /\end{array}$} & \multirow{2}{*}{$\begin{array}{l}\text { Need } \\
\text { index }\end{array}$} & \multicolumn{2}{|c|}{$\begin{array}{l}\text { Hay fodder } / 100 \\
\mathrm{~kg} /\end{array}$} \\
\hline & & & 2018 & 2023 & 2018 & 2023 & & 2018 & 2023 \\
\hline Horse & 39655 & 44123 & $\begin{array}{c}26172 \\
3\end{array}$ & $\begin{array}{c}29121 \\
1\end{array}$ & 502508 & 559126 & 0.05 & 25125 & 27956 \\
\hline Cattle & 22758 & 23642 & $\begin{array}{c}11379 \\
0\end{array}$ & $\begin{array}{c}11821 \\
0\end{array}$ & 218476 & 226963 & 0.05 & 10923 & 11348 \\
\hline Sheep & $\begin{array}{c}10937 \\
1\end{array}$ & $\begin{array}{c}14309 \\
2\end{array}$ & $\begin{array}{c}10937 \\
1\end{array}$ & $\begin{array}{c}14309 \\
2\end{array}$ & 209992 & 274736 & 0.05 & 10499 & 13736 \\
\hline Goat & $\begin{array}{c}10780 \\
5\end{array}$ & $\begin{array}{c}15452 \\
4\end{array}$ & 97024 & $\begin{array}{c}13907 \\
1\end{array}$ & 186287 & 267017 & 0.05 & 9314 & 13350 \\
\hline Camel & 717 & 893 & 6166.2 & 7679 & 11839 & 14745 & 0.05 & 591 & 737 \\
\hline Total & $\begin{array}{c}28030 \\
7\end{array}$ & $\begin{array}{c}36627 \\
3\end{array}$ & $\begin{array}{c}58807 \\
5\end{array}$ & $\begin{array}{c}69926 \\
5\end{array}$ & 1129103 & 3985812 & & 56455 & 67129 \\
\hline
\end{tabular}

Table 3 presents that the number of livestock in Erdenetsagaan soum will be increased to 699265 sheep unit in 2023. In order to supply the abovementioned domestic animals, it is necessary to prepare 398581 ton hays for whole year feeding or 5 $\%$ of total need (need index) will be 6712 ton during winter season (120 days) in 2023. The Erdenetsagaan soum is one of the key areas for haymaking in the Sukhbaatar aimag. Consequently, it is possible to prepare these resources using local areas hayfield (table 4), and for the preparation of necessary feedstuffs, it is assumed to require about yield of 800 $\mathrm{kg}$ of hay per hectare $[7,11]$.

Area required for preparing needed hay fodder

\begin{tabular}{ccccccc}
\hline \multirow{2}{*}{ Livestock } & \multirow{2}{*}{2018} & \multirow{2}{*}{2023} & \multicolumn{2}{c}{ Hay fodder $/ 100 \mathrm{~kg} /$} & \multicolumn{2}{c}{ Required hay land $/ \mathrm{ha} /$} \\
& & & 2018 & 2023 & 2018 & 2023 \\
\hline Horse & 39655 & 44123 & 25125.4 & 27956.3 & 3140.67 & 3494.54 \\
Cattle & 22758 & 23642 & 10923.8 & 11348.2 & 1365.48 & 1418.52 \\
Sheep & 109371 & 143092 & 10499.6 & 13736.8 & 1312.45 & 1717.10 \\
Goat & 107805 & 154524 & 9314.35 & 13350.9 & 1164.29 & 1668.85 \\
Camel & 717 & 893 & 591.955 & 737.261 & 73.99 & 92.15 \\
Total & 280307 & 366273 & 56455.2 & 67129.5 & 7057 & 8391 \\
\hline
\end{tabular}

The table above shows that in 2018, 5645 ton and 6712 ton hay fodder in 2023 are needed. The need for hay fields in 2023 [7,11].

Table 4.

this feed supply requires 7057 hectares in 2018 and 8391 ha

Hay land planning

\begin{tabular}{|c|c|c|c|c|c|c|}
\hline \multirow{2}{*}{ № } & \multirow{2}{*}{ Hay land use zone } & \multirow{2}{*}{ Area, ha } & \multicolumn{2}{|c|}{ Hay fodder $/ 100 \mathrm{~kg} /$} & \multicolumn{2}{|c|}{ Required hay land /ha/ } \\
\hline & & & $\frac{\infty}{\stackrel{\sim}{i}}$ & ֶิ ญి & 2018 & 2023 \\
\hline $\begin{array}{l}1 \\
2\end{array}$ & $\begin{array}{l}\text { Current area for } \\
\text { haymaking } \\
\text { Suitable areas for } \\
\text { haymaking }\end{array}$ & $\begin{array}{l}10343 \\
58785\end{array}$ & 56455 & 67129 & 7057 & 8391 \\
\hline
\end{tabular}


As shown in the above table, the soum uses 10343 hectares of hayfields for 2017 and is fully capable of providing the necessary feedstuffs for the planning period. Furthermore, there is a potential 58785 ha reserve area for haymaking purposes, which can be developed as a major hayfield at the national level (Figure 3).

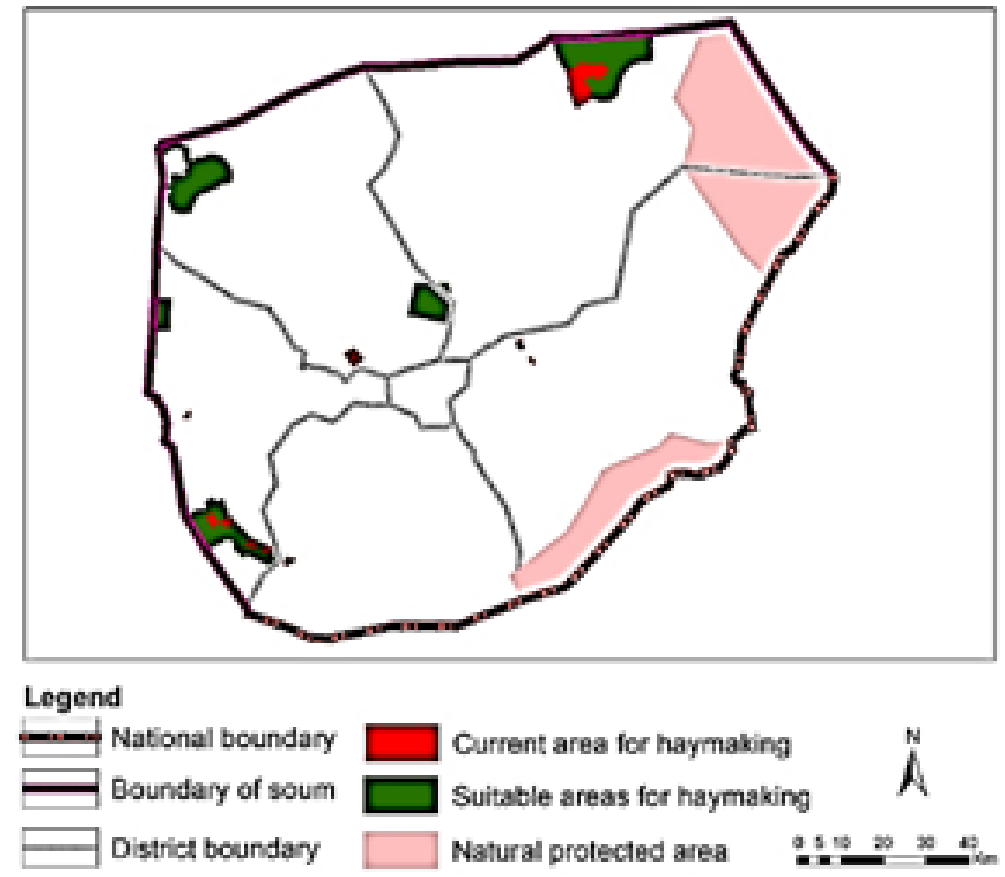

Figure 3. Hay land use planning

\section{DISCUSSION AND CONCLUSION}

According to the tested new suitability assessment of hay land, 4.37 percent or 74164 ha of land are most suitable, and 29.21 percent or 496014.3 ha are unsuitable. In order to calculate the nutritional needs of livestock in the future, the demand of green fodder for hay cut is estimated at $6712 \mathrm{t}$ in 2023 . The need for this fodder supply requires 8391 ha hay fields in 2023.
Erdenetsagaan soum uses 10,343 hectares of hayfields for 2017 and is fully capable of providing the necessary feedstuffs for the planning period to 2023. Furthermore, there is a potential 58785 ha reserve area suitable for haymaking purposes, which can be developed and transferred from pastureland to hayland as a major hayfield at the soum 1 level in near future.

\section{ACKNOWLEDGEMENT}

We would like to thank the Sukhbaatar Aimag Department of Land Administration and the Land Regulation Officer of Erdenetsagaan Soum for their support.

\section{REFERENCES}

[1] Jargal. E. 2018. Does global warming benefit Mongolia? News.mn online magazine. Accessed 2018.03.15 https://www.news.mn/?id=273419

[2] P.Myagmartseren and I.Myagmarjav., 2017. Cropland suitability assessment and confusion matrix evaluation with GIS. Mong.J.Agric.Sci.(2017) Vol.21 (02): DOI: http://dx.doi.org/10.5564/mjas.v21i02.911
[3] Baban S.M.J, and Wan-Yusof K., (2003) "Modeling Optimum Sites for Locating Reservoirs in Tropical Environments", Water Resources Management, pp. 17, 1-17.

[4] Brandt, S.A., 2006. AHP v. 2.0. Analytic hierarchy process software. Available from: http://sab.geovega.se/lattjo.html

[5] ALAGaC. 2017 Guidelines: Methodology for developing soum land use development plans.Ulaanbaatar. 
[6] Saaty. T., (1977). "A scaling method for priorities in hierarchical structures". Journal of Mathematical Psychology, vol. 15(3), pp. 234281.DOI:10.1016/0022-2496(77)90033-5

[7] State Land Use Planning, Survey, Project Design Institute. 1988. "Guidance on mapping and surveying of natural pasture and hay land". Ulaanbaatar

[8] Purevtseren G. 1990. Land Quality assessment methodology. Project report. Ulaanbaatar. Land Policy Institute.
[9] Ministry of Food, Agriculture and Light Industry. 2013. Recommendation on proper composition of livestock and recommendation of herd circulation. UB

[10] Land Administration, Geodesy and Cartography Agency. 2017. Methodology for developing soum development plans. UB Geobotanic Company Ltd. 2018. "Report on the land use development plan of the territory of Erdenetsagaan soum, Sukhbaatar aimag", Ulaanbaatar. 